\title{
A Study of Human Resources Management Practices and Labour Turnover in the Manufacturing Organisations in Lagos, Nigeria
}

\author{
Oginni Babalola Oluwayemi ${ }^{1}$, Afolabi Gbadegeshin Victor ${ }^{2}$ \\ ${ }^{1,2}$ Department of Economics and Business Studies, Redeemer's University, Mowe - Ogun State, Nigeria
}

\begin{abstract}
The research focus was on the human resources management practices and its impact on labour turnover with reference to manufacturing organisations in Lagos State, Nigeria. The paper identified HRM practices in the two dimensions of economic cycles which were boom and recession periods. It investigated and assessed which of the HRM practices affect labour turnover under different economic cycles. The population of study consists of 156 organisations obtained through a preliminary survey of manufacturing organisations in the three senatorial districts of Lagos state namely Lagos West, Lagos Central and Lagos East which was based on the number of years of existence and a sample of 99 organisations representing 63\% (33 from each of the senatorial district) was randomly selected from purposively chosen manufacturing organisation in Lagos which covers Agro industry, Confectionery, Brewery and Beverage businesses. The questionnaire was developed by using a five point Likert scale which was administered to a total number of 36 respondents who were General Managers/Administrative Executive, Human Resources Directors/Human Resources Managers or Managing Directors from each senatorial district totalling to 108 respondents. Descriptive statistics and simple percentage were used to analyse and interpret the data collected. The study reveals that HRM practices such as wages and salary, training and development, recruitment and placement as well as employee relations, performance appraisal, career development and lay off procedures were found in the boom and recession economic periods. The focus of the practices was on satisfaction of employees in order to prevent high labour turn over in the boom period while the focus of the practices in the recession period was mainly on organisational survival by way of cutting cost most especially in the area of human resource. It was recommended that the management of the organisations in the manufacturing sectors should understand the prevailing economic cycle so as to know the focus of their HRM practice, the department of human resources should be headed by an expert in the art of human resources management so as to provide dynamism in the wake of stiff hostility and favourable conditions in the business environment.
\end{abstract}

Key Words: Human resources management practice, Labour turnover, Manufacturing, senatorial district, and economic cycles.

\section{Introduction}

Success in the field of human relationships in the world of work stems from good human resources management (HRM) policy, practice, and effective personnel functions (Mullins, 2001[1]). Whatever the nature of the work organisation, an organisation achieves results through the work activities of people in the organisation provided for by the policies and practices of HRM guiding their respective activities. Therefore, HRM practices are reflections of policies put in place to guide employees in the course of taking action or decision that will direct the activities which have consequences on the overall behaviour in the organisation. The personnel functions are compressed in the term HRM. For Nigerian manufacturing organisations to survive in a global economy in this present millennium, they need to design effective human resources management (HRM) practices that encourage the retention of high performing employees, particularly among employees with core skills and should develop competitive practices to retain them. This must not be left at the door step of the personnel department only but should be seen as responsibility to be shared by other units in the organisation (Mullins, 1985[2]).

\subsection{STATEMENT OF THE PROBLEM}

The movement of employee from one job to another either in the same industry or outside the industry, it is always traced to a reason which can be one or combination of substantial or procedural matters (Oginni and Faseyiku, 2012[3]) and it is contingent upon prevailing economic situation in the environment. It is predicted that under different economic cycles (Prosperity, Boom, Recession and Depression), different HRM practices have differential impact on employee turnover because each has its own peculiarity aside the fact that organisation's resources are limited which also impinged on the ability of the organisation to develop best practices in all of their activities in short span of time. Typically, in an economic recession, employees are less willing to quit their jobs because there are fewer employment options available. Therefore, everything else being 
equal, those who do quit during an economic recession may have to be more dissatisfied with certain HRM practices compared to those who quit during an economic boom. Hence, this study

\subsection{OBJECTIVES}

The broad objective of the study was to understand existing relationship between human resources practices and labour turnover along the economic cycles. From this broad objective, some specific objectives were being derived;

1. To identify which of the HRM practices are in use often during the different economic cycles.

2. To investigate which HRM practices affect employee turnover under different economic cycles.

3. To assess which of the HRM practices have greater marginal impact on labour turnover during different economic cycles.

\subsection{RESEARCH QUESTIONS}

The following questions were raised to guide the direction of the research work:

1. What are HRM practices being used frequently during the different economic cycles?

2. Which of the HRM practices affect employee turnover more under different economic cycles?

3. Which of the HRM practices have greater marginal impact on labour turnover during different economic cycles?

\subsection{SIGNIFICANCE OF THE STUDY}

It has revealed the role of HRM practices in the wake of controlling labour turnover with reference to economic cycles. It has equally provided a good framework to understand which of the HRM practices affect labour turnover more in a particular economic cycle through explicit investigation into the boom and recession economic periods. The variables in the HRM practices were also identified.

\subsection{LIMITATION OF THE STUDY}

The study was limited to the three senatorial districts in Lagos using the manufacturing organisations in this area as focus of study. The study was also confined to boom and recession economic cycles.

\section{Literature Review}

Past researches have linked various human resource management practices to employee turnover. For example, realistic job previews, selection procedures, socialization programs, promotion opportunities, and compensation practices were found to affect employee turnover most especially during economic boom cycle.

\subsection{RELATIONSHIP BETWEEN HUMAN RESOURCES PRACTICES AND LABOUR TURNOVER 2.1.1Recruitment, Selection, Placement and labour turnover}

Firms that do not select the right employees to begin with may not be able to keep these employees in the long run because of low employee morale arising from a poor job fit. Also, firms that do not socialize new employees into their jobs and/or the organisation may not be able to cultivate from them, a sense of loyalty and commitment to the firm because of the lack of attachment demonstrated by the firm to the newcomers.

In the area of selection tools, Kettlitz, Zbib and Motwani (1997[4]) found that firms that used the weighted applications blanks (WABs) to screen job candidates had lower employee turnover. This was because the use of WABs reduced the number of poor candidates selected for employment to begin with which was a proactive approach to reducing turnover among those not suitable for the job. This finding supported Brockner, (1992 [5])'s results which found that job compatibility predicted employee turnover. Firms that was able to assess if individuals were compatible for the jobs they applied for, were more able at reducing employee turnover. Specifically, firms that used an application review, reference check and interview to assess job applicants' job compatibility had lower employee turnover.

Conversely, employees' perception of the organisational and job fit were also factors that have an effect on employee turnover. For example, McElroy etal (2001 [6]) found that voluntary employee turnover was contingent on the amount of fit/misfit between the individual's values and the predominant organisational structure/management style. Employee turnover was therefore the result of an interaction between personal factors and organisational factors.

\subsubsection{Compensation and labour turnover}

The works of Shaw etal (2005 [7]) on compensation package shows that salary growth had a pronounced effect on turnover, most especially for high performing employees. Park, Ofori-Dankwa and Bishop (1994[8]) also found that turnover is negatively associated with levels of pay. Most obviously, firms that do not pay their employees equitably compared to what other firms are paying, may lose their employees because of 
the non-competitive compensation package. Where pre-selection practices are concerned, Pitt and Ramaseshan (1995[9]) found that individuals who displayed a higher tendency to leave their jobs were those who perceived that the job previews that they received during the interview process were not realistic. Specifically, individuals expressed that the relevance, depth and accuracy of job information were important to them. These factors were found to be strong predictors of an individual's propensity to leave. The results therefore suggest that a lack of interview quality, rather than information quantity, during a realistic job preview, affected employees' intentions to leave.

\subsubsection{Role of Conflict Management and labour turnover}

When individuals did not fit the job expectations, Dubinsky, Dougherty and Wunder (1990[10]) found that role stress led to job dissatisfaction and intentions to quit. The stress caused poor job fit ultimately led to the employees actually quitting their jobs. Particularly, women who felt that their expectations had not been met had greater intentions to leave as a result of low job satisfaction and organisational commitment (Rosin \& Korabik, 1991[11]). Unmet expectations included limitations in leadership, responsibility, personnel policies, time flexibility and autonomy. Their findings highlighted the importance of assisting employees to resolve their role conflict. Another aspect was role over loaded which also have adverse effect on labour turnover. Major, Kozlowiski, Chao and Gardner (1995[12]) investigated if role expectations namely conflict, clarity and acceptance as well as organisational fit, particularly in relationship with supervisors and team members affected turnover intentions. The results showed that the met expectations in one's job as well as supervisors and team members were significant predictors of employee turnover intention.

\subsubsection{Promotion and labour turnover}

Miller and Wheeler (1992[13]) found that meaningful work and opportunities for promotion significantly affected employees' intentions to leave an organisation. Organisations were able to improve their employees' retention rates particularly among female managers, by adopting job enrichment programs and enhancing their advancement opportunities. Besides promotion opportunities, the evaluation criteria used in the promotion and reward system also had significant effects on employees' turnover intentions (Ouarles, 1994[14]). According to Fajana (2001[15]), management of organisation should endeavour to avoid Peter principles which is promoting employee above their capability as such upward movement can exposed weaknesses of such employee and frustration can set in which can inevitably lead to exit at the long run.

\subsubsection{Performance Appraisal and labour turnover}

The purpose and nature of the appraisal system should be made clear. Performance appraisal should be established on regular dialogue and lead on an improvement in manager - staff relationships. Mullins (2001[1]) was of the opinion that such system should focus on the strengths and accomplishment of staff, rather than their faults and failures, and it should lead to a plan for the future development and progress. It should not be viewed in isolation but in relation to corporate objectives of the organisation, and designed to suit its culture and particular requirements. The procedure should be understood by all and sundry in order to have credibility and maintain goodwill (Weitzel, 1987[16]). Ineffective performance appraisal and planning systems contributed to employees' perceptions of unfairness and they were more likely to consider leaving the organisation (Dailey \& Kirk, 1992[17]).

\subsubsection{Training and Development and labour turnover}

People are a crucial, but expensive resource. In order to sustain economic and effective performance it is important to optimise the contribution of employees to the aims and goals of the organisation. Oginni etal (2007 [18]) asserted that investing in people is a standard for the training and development of people within an organisation in order to improve knowledge and skills, and to change attitudes thereby leading to increase in confidence, competence level, commitment, motivation as well as recognition. Further enhance responsibility, feeling of personal satisfaction, career progression, sense of achievement and sometimes accompany with increase in pay and promotion. The works of Langeland etal (2006[19]) revealed that some organisations were sceptical and have reservations about the cost and extent of tangible business return from training and development given to employees most especially the departure of such employee from the organisation within shortest period of time and thus concluded that training and development gives employees opportunities to be abreast with the trends of activities in their chosen career and therefore prone to head haunting or poaching.

\subsubsection{Employee Relations and Labour Turnover}

This is concerned with the relationship between the policies and practices and its staff, and the behaviour of work groups (Mullins, 2001[1]). Employee relations is contingent upon sound personnel policies which is influenced by type, nature, size of organisation, structure, methods of operation, nature of staff 
employed, philosophy and attitude of top management(Peacock and Mullins, 1992[20]). It is this areas covered by the policies that will determine the kind of relationship between employees and the organisation. Sometimes the organisational management see the work place from unitary or pluralistic perspectives and thus inform the operational personnel policies in the organisation. An IDP position paper (1992[21]) posits that there is a positive link between employee relations and labour turnover. It was deduced that employment relationship borne out of contract of employment has propensity to determine whether employee will stay or leave the organisation. Mullins (2001[1]) asserts that the responsibility of employee relations is contingent upon line manager's attitudes and that sound personnel policy will enable employers to develop and draw on the full potential of their employees provided human resource department are close contact with the line managers.

\subsubsection{Human resources planning and labour turnover}

This is sometimes refers to as manpower planning and it is being described as the acquisition, utilisation, improvement and retention of an enterprise's human resources (Akindele, 2007[22]). HRP should be developed as an integral part of the broader process of corporate planning and should be related to the organisational climate and culture in order to respond to the challenges and influences in the internal and external environment so as to contribute its quota to the overall success of the organisational objectives (Nkomo, 1986[23]). In the views of Akindele (2007[22]) HRP involves considerable uncertainty as it tries to foresee changes and identify trends in staffing resources as well as adopting personnel policies that would help to avoid major problems in recruitment and selection processes in the shortest distance. However, Beardwell and Holden (2001[24]) believed that the importance of HRP lies in maintaining a sufficient supply of employees, in the right size, place, and time and at the right cost. Therefore, labour turnover experienced in HRP is involuntary as evidence in restructuring, downsizing, right sizing, and reorganisation, retrenchment and reengineering of employees in the organisation. Many a time most of these are initiated by management as a result of changes in political and socio - economic conditions (Whiddett and Kandola, 2002[25]).

The above review shows that organisational human resource practices have significant impact on labour turnover. Sailors and Sylvester (1996[26]) suggested that to retain efficient and productive employees, organisations should provide employees with an enriched packages through sound practices of HRM.

\section{Methodology}

The research work made use of primary and secondary data. Primary data were obtained through the administration of structured questionnaire developed in line with 5-point Likert type scale to elicit relevant information on human resource management practices and labour turnover. The population of study consists of 156 organisations obtained through a preliminary survey of manufacturing organisations in the three senatorial districts of Lagos state namely Lagos West, Lagos Central and Lagos East which was based on the number of years of existence and a sample of 99 organisations representing 63\% (33 from each of the senatorial district) was randomly selected from purposively chosen manufacturing organisation in Lagos which covers Agro industry (8), Confectionery (9), Brewery (8) and Beverage business (8). From which questionnaires were administered to a total number of 36 respondents who were General Managers/Administrative Executive, Human Resources Directors/Human Resources Managers or Managing Directors from each senatorial district and totalling to 208 respondents. They were chosen as respondents because as senior manager, they have a more strategic overview of the organisation's HRM practices and operations. The secondary data used in the research were obtained from records of the purposively chosen manufacturing organisations which covers the period of economic boom in Nigeria. Descriptive statistics, factor analysis and inferential analysis were made used thus, enabling meaningful deduction.

\section{Analysis And Findings Interpretation}

Table 1: Information on HRM Practices during economic boom in Nigeria

\begin{tabular}{|c|c|c|c|c|c|c|c|}
\hline $\mathbf{S} / \mathbf{N}$ & HRMP Variables & West & Central & East & Total \% & Total Mean & Mean Rank \\
\hline 1 & Training and development & 5 & 6 & 4 & $15(42 \%)$ & 1.7 & 1 \\
\hline 2 & Employee relations & 4 & 4 & 3 & $11(31 \%)$ & 1.2 & 3 \\
\hline 3 & Promotion and transfer & 2 & 2 & 3 & $7(19 \%)$ & 0.8 & 5 \\
\hline 4 & Wages and salary administration & 5 & 4 & 6 & $15(42 \%)$ & 1.7 & 1 \\
\hline 5 & Performance appraisal & 4 & 3 & 4 & $11(31 \%)$ & 1.2 & 3 \\
\hline 6 & Conflict management & 4 & 3 & 3 & $10(28 \%)$ & 1.1 & 4 \\
\hline 7 & Recruitment and placement & 5 & 4 & 5 & $14(39 \%)$ & 1.6 & 2 \\
\hline 8 & Lay off procedure & 4 & 5 & 5 & $14(39 \%)$ & 1.6 & 2 \\
\hline 9 & Career development & 3 & 5 & 3 & $11(31 \%)$ & 1.2 & 3 \\
\hline & Total & 36 & 36 & 36 & & & \\
\hline
\end{tabular}

Source: survey 2012 
Table 1 contains cumulative information about HRM practices as it was commonly found during economic boom in Nigeria some years back. The mean rank shows the practice that is common to all the organisations which was wages and salary administration with $42 \%$, the result was in respect of compensation package that has kept employees in their place of work as well as training and development with $42 \%$. The implication was that there is policy that supports training and development of employees irrespective of their position in the organisation and it was understood by all. It was followed by the sound policy in respect of disengagement of employees with $39 \%$ which shows a formalised process. In the same category was recruitment and placement with $39 \%$ indicating fairness in the employment processes as well as matching qualification(s) with position occupied. Employee relations, career development and performance appraisal were next with $31 \%$ each. The HRM practices brought about good employee relations as they were exposed to good salary, frequent training and mutual separation where it is necessary. Career development was equally enhanced by recruitment and placement which has bearing on the progression in the organisation with result from performance appraisal as the indicator. Conflict management followed with $28 \%$. It was evident from the data obtained that this was not frequently used as conflict was not quite visible therefore the policy in place was not subjected to test of time but it was provided for. The last variable in the HRM practice was promotion and transfer with $19 \%$. The implication was that the policy emanating from recruitment and placement favours sourcing for candidates outside the organisation to fill most of the existing vacancy and use promotion and transfer to fill others (sensitivity, nature or history).

Table 2: Information on HRM Practices during economic recession in Nigeria

\begin{tabular}{|c|c|l|l|l|l|c|c|}
\hline S/N & HRMP Variables & West & Central & East & Total \% & $\begin{array}{l}\text { Total } \\
\text { Mean }\end{array}$ & $\begin{array}{l}\text { Mean } \\
\text { Rank }\end{array}$ \\
\hline 1 & Training and development & 2 & 3 & 2 & $7(19 \%)$ & 0.8 & 5 \\
\hline 2 & Employee relations & 5 & 4 & 4 & $13(36 \%)$ & 1.4 & 3 \\
\hline 3 & Promotion and transfer & 2 & 3 & 2 & $7(19 \%)$ & 0.8 & 5 \\
\hline 4 & Wages and salary administration & 2 & 3 & 2 & $7(19 \%)$ & 0.8 & 5 \\
\hline 5 & Performance appraisal & 4 & 3 & 2 & $9(25 \%)$ & 1.0 & 4 \\
\hline 6 & Conflict management & 7 & 7 & 6 & $20(56 \%)$ & 2.2 & 1 \\
\hline 7 & Recruitment and placement & 5 & 4 & 7 & $16(44 \%)$ & 1.8 & 2 \\
\hline 8 & Lay off procedure & 7 & 6 & 7 & $20(56 \%)$ & 2.2 & 1 \\
\hline 9 & Career development & 2 & 3 & 2 & $7(19 \%)$ & 0.8 & 5 \\
\hline & TOTAL & 36 & 36 & 36 & 208 & & \\
\hline
\end{tabular}

Source: survey 2012

Table 2 has information about HRM practices during economic recession as it is currently experienced in Nigeria. The information provided here is far cry from that of table 1 as revealed by the mean rank because the response was in relation to how recession has affected the sound practice of HRM. Conflict management and lay off procedure became the most commonly used HRM practices with 56\% each. The implication was that there is expression of dissatisfaction on issues which are visible or not, leading to termination of employment by either party. The information revealed through the data obtained shows that it was more of the employer than employee and thus put pressure and attention on policies in respect of disengagement and conflict management. This was followed by the policy in terms of recruitment and placement with $44 \%$ which place premium on filling vacancies in way that is peculiar to her mode of operations, here godfatherism and nepotism took the place of fairness and meritocracy among the job seekers; qualification (s) no long play a significant role in job placement except in some major professions even at that the practice is still the same. Next on the ladder was employee relations with $36 \%$ since there is conflict of interest in the work place leading lost of job, the outcome is strain in the employee/employer relations because the absence of the alternative job will not allow employee to leave and this also strengthened employers' power as employee cannot leave. This was followed by performance appraisal with $25 \%$ which was suppose to assist other practices was used as determinant to know who to keep or who to go. The last variables in the HRM practices were career development, training and development as well as wages and salary administration each with 19\%. The implication was that the problem generated from recruitment and placement practices, affected the development of sound policy to support career development and thus affected the need to implement to the letter policy on employees' training and development. The wages and salary administration was affected by economic recession which has reduced the economic profitability of organisational products, most especially the epileptic supply of electricity thus increasing cost of production since organisations now depend on alternative source of power supply. 


\section{Discussions Of Findings}

With reference to the objective of the study, the following were identified as the HRM practices in the manufacturing organisations in Lagos State to include training and development, wages and salary, promotion and transfer, employee relations, career development, performance appraisal, lay off procedure, conflict management, recruitment and placement for the two economic cycles. In the boom period, wages and salary administration, training and development, recruitment and placement as well as employee relations, performance appraisal, career development and lay off procedures were often used. The focus of the practices was on satisfaction of employees in order to prevent high labour turn over. This period witness increase in the profitability rate of the manufacturing organisations which enable them to develop robust and sound practices in wages and salary administration leading to competent personnel willing to join the organisations, funds were equally made available for training which is a form of investment in employee thus standing as security for the job. It is therefore in order to say that the HRM practices among variables identified were evenly distributed where as in the recession period; all these variables were also made used ranging from training and development to career development but the focus of the practices were not on employee satisfaction to prevent high labour turnover, it was mainly on organisational survival by way of cutting cost most especially in the area of human resources. This explains why recruitment policy moved away from meritocracy to mediocrity since there is exodus of all kinds as a result of frustration. This affected the willingness on the part of management to send employees on training courses, thus generating conflict of interests and the policy in support of career development cannot be sustained. The HRM practice in operation during recession period is somewhat hostile and unfavourable to employees; this may be a result of the general level of business activities which is generally low in all its ramifications but during the boom period, the HRM practice is always friendly and favourable to employees.

\section{Conclusion}

It is quite evident that the HRM practices in two economic cycles were not the same which means there can never be the same result. The practice of HRM during boom period will definitely have low labour turnover because of the characteristics of the period which made provision of some luxuries possible and witness business expansions. However, the practice of HRM during recession period will definitely have high labour turnover considering the nature of competition in the midst of scare resources as well as inflation thus heralding price instability which will affect price of raw materials for productions. To this extent, it will not be out of place to say that during the boom period wages and salary inform of competitive pay, lay off procedure inform of job security, training and development inform of goodwill in the of eye of employee and public, promotion inform ego boost will affect labour turnover on account of the favourable conditions in the business environment. During the recession period, wages and salary inform of competitive pay, employee relations to forestall dissatisfaction and conflict management to forestall disaffection will affect labour turnover on account of the hostility in business environment. However, on the basis of the analysis wages and salary administration will have marginal impact on labour turnover irrespective of the economic cycles being experienced.

\section{Recommendations}

In view of the findings and discussions above, it is recommended that the management of the organisations in the manufacturing sectors should understand the prevailing economic cycle so as to know the focus of their HRM practice, the department of human resources should be headed by an expert in the art of human resources management so as to provide dynamism in the wake of stiff hostility and favourable conditions in the business environment. Wages and salary should be made competitive to reduce labour turnover and be paid as when due for stability purpose on the part of the employees. The existing lay off procedure practices should be reviewed so as to offer fairness and justice to the procedure and cooperation that will foster coworkers and management relationships in order to create an atmosphere free of fear and tension should be created thus heralding good working relationship. Finally, the practice where anybody is being recruited into the organisation on the basis of being a university graduate should be jettisoned rather match qualification(s), job experience and prerequisite skills with position to be occupied or filled so as to reduce the rate of labour turnover in the manufacturing sector of the economy.

References

[1] L.J. Mullins, Management and Organisational Behaviour $6^{\text {th }}$ ed. (UK, Pitman Publishing imprint, 2001) (16),(21)(24)

[2] L.J Mullins, The personnel function - shared responsibility, Administrator, vol. 5(5), 1985, 14-15

[3] B.O. Oginni and I. O Faseyiku, Fundamentals of Human Capital Management, A process approach, (Lagos, Mankore Print Ltd, 2012)

[4] Kettlitz, G.R, Zbib, I and Motwani, J, Reducing nurse aide turnover through the use of weighted applications blank procedure, The Health care supervisor vol. 16(2), 1997, 41-47

[5] J, Brockner, Managing the effects of Layoff on others, California Management Review, 1992, 9-27. 


\section{A Study of Human Resources Management Practices and Labour Turnover In The Manufacturing}

[6] C. McElroy, James, C. Morrow Paula and N. Scott Rude, Turnover and organisational performance: A comparative analysis of the effects of voluntary, involuntary and reduction-in-force turnover, Journal of Applied Psychology, 86(6), 2001, 1292 - 1299.

[7] Shaw, Jason D, Gupta, Nina and John E. Delery (2005): Alternative conceptualisations of relationship between voluntary turnover and organisational performance, Academy of Management, 48(5), 50 - 68

[8] Park, H.Y, Ofori-Dankwa, J and Bishop, D.R, Organisational and environmental determinants of functional and dysfunctional turnover, Practical and research implications, Human Relations, 47(3), 1994, 353-366

[9] L.F, Pitt, and B, Ramaseshan, Realistic job information and sales force turnover, an investigative study, Journal of Managerial Psychology, 10(5), 1995, 29-36

[10] A.J Dubinsky, T.W, Dougherty and R.S Wunder, Influence of role stress on turnover of sales personnel and sales managers, International Journal of Research in Marketing, 7(2/3), 1990, 121-133.

[11] H,M Rosin and K, Kobark, Workplace variables, affective responses and intention to leave among women managers, Journal of Occupational Psychology, 64(4), 1991, 317-330

[12] D.A Major, S.W.J, Kozlowski, G,T Chao and P,D Gardiner, A longitudinal investigation of newcomers expectations, early socialization outcomes and the moderating effects of role development factors, Journal of Applied Psychology, 80(3), 1995, 418431

[13] J.G Miller and K,G Wheeler, Unravelling the mysteries of gender differences in intention to leave the organisation, Journal of Organisational Behaviour, 13(5), 1992, 465-478

[14] R, Quarles, An examination of promotion opportunities and evaluation criteria as mechanisms for affecting internal auditor, Journal of Managerial issues 6(2), 1994, 176-194

[15] S, Fajana Human resource management, an introduction, (Lagos, Labofin and company, 2002).

[16] W. Weitzel, How to improve performance through successful Appraisal, Personnel, 64(10), 1987, 18-23

[17] R.C Dailey and D,J Kirk, Distributive and procedural justice to antecedents of job dissatisfaction and intention to turnover, Human Relations, 45(3), 1992, 305-317

[18] B.O Oginni, N.O, Ajayi, and I.O Adebayo, Management, a practical approach, (Lagos, Kay Publishing Ltd, 2005)

[19] K.L Langelander, C.M Johnson and T.C Mawhinney, Improving staff performance in acommunity mental health setting: Job analysis, training, goal setting, feedback and years, Journal of Organisational Behaviour Management, 18(1), 1998, 21-43

[20] A, Peacock and L.J Mullins, Effective employee relations, behavioural Dimensions Administrators April, 1992, 12-13

[21] Employment relations into the $21^{\text {st }}$ Century: An IPD Position paper, Institute of Personnel and Development, December, 1997, 1

[22] R.I Akindele, Fundamental of human resources, (Ile - Ife, Cedar Publishing Productions, 2007) (27)

[23] S.M Nkono, The theory and practice of human resource planning: the gap still remains, Personnel Administrator, 31(8), 1986, 7183

[24] I. Beardwell and Holden, Human Resource Management, a contemporary approach, $3^{\text {rd }}$ ed. Financial Times Prentice Hall, 2001)

[25] S, Whiddett and B, Kandola, Fit for the Job, People Management, May 2000, 33-38

[26] J.F Sailor and J, Sylvestre, Reduce the cost of employee turnover, Journal of Compensation and Benefits, 9(5), 1994, 32-34 